\title{
Factors Affecting Freshman Engineering Students' Attitudes Toward Mathematics
}

\author{
Essa A. Alibraheim ${ }^{1 *}$ \\ ${ }^{1}$ Assistant Professor, Curriculum and Instruction, Imam Abdulrahman Bin Faisal University, SAUDI ARABIA
}

Received 6 November 2020 - Accepted 8 May 2021

\begin{abstract}
Students' attitudes toward mathematics play a key role in their academic achievements. Still, concerns regarding the low grades in mathematics tests of engineering students have raised questions about the reasons for their poor performance. Prior research has mentioned the impact of engineering students' attitudes on their grades. Few studies have attempted to explore the factors that influence and form engineering students' attitudes toward mathematics. The current study aims to investigate the factors that affect freshman engineering students' attitudes toward mathematics using a qualitative research design. Interviews with 26 participants enrolled at Imam Abdulrahman Bin Faisal University (IAU) in Saudi Arabia provided insight into the students' experiences through survey questions. Thematic content analysis was used in this study to analyze the interviews. The results of the interview indicate that the freshman engineering students' attitudes are most affected by their fathers and their teachers. The causes that form students' attitudes toward mathematics can be divided into two parts: internal and external. The internal causes result from the students themselves, which include practice and preparation, assessments and grades, effect of English proficiency, and time management. The external causes include teachers' characteristics and parental support.
\end{abstract}

Keywords: university education, freshmen engineering students, attitudes toward mathematics, Saudi Arabia

\section{INTRODUCTION}

Mathematics is a primary aspect of several majors, including engineering. In engineering programs, students must register for many mathematics courses. Therefore, many of the students consider mathematics and the math professors' teaching style to be an academic hurdle, especially during their freshman year (Eng, Li, \& Julaihi, 2010; Goold, 2012; Harris et al., 2015; Prakash, Jerlin \& Fernandes, 2014; Prakash, Kannan, \& Jerlin, 2014). Many engineering students fail or get low grades in their first mathematics courses, such as Calculus I (Mwavita, 2005; Kafata \& Mbetwa, 2016; Prakash et al., 2014; Varela, 2014). One of the reasons for quitting school among freshman engineering students is their poor performance in mathematics (Goold, 2012; Mwavita, 2005). Therefore, finding the causes of this phenomenon will help engineering students overcome this issue. In this context, many studies confirmed that a student's attitude towards mathematics is one of the main causes of this phenomenon (Eng, Li, \& Julaihi, 2010; Kafata \& Mbetwa, 2016; Syam \& Salim, 2014).

According to Goodykoontz (2008), and Eng et al. (2010), the students' attitudes towards mathematics affect their academic achievement; thus, a more positive attitude may increase their performance in the subject. A study conducted by Kafata and Mbetwa (2016) confirmed that most students in Zambia reported that their poor performance in mathematics was due to their negative attitude towards the subject. Furthermore, Syam and Salim (2014) claim that university students who are not enrolled in a mathematics major have a negative attitude towards the subject, thus affecting their performance in mathematics courses. Similarly, Huang (2011) asserted that a high percentage of engineering students have negative attitudes toward calculus, causing them to fail. This result is confirmed by the study conducted by Prakash et al. (2014) in which they

(c) 2021 by the authors; licensee Modestum. This article is an open access article distributed under the terms and conditions of the Creative Commons Attribution License (http://creativecommons.org/licenses/by/4.0/).

$\square$ ealibraheim@iau.edu.sa (*Correspondence) 


\section{Contribution to the literature}

- Although research has acknowledged the impact of students' attitudes toward mathematics on their academic performance, few studies have attempted to explore the factors that contributed to their attitudes.

- This study attempts to contribute to the educational research by investigating the factors that influence freshman engineering students' attitudes toward mathematics using a qualitative research design, which allows for deep understanding and a more comprehensive analysis of the data.

- This study offers three reasons for the freshman engineering students' positive attitudes toward mathematics: teachers' positive characteristics, parental support, and practice and preparation.

identify one of the causes for the failure of engineering students in mathematics as seeing mathematics as a difficult subject that causes anxiety from an early age.

In the past 40 years, many reports in the literature on attitudes of students have been concerned with developing several instruments of measurement which are used to examine students' attitudes toward mathematics and test its relationship with many variables such as academic achievement (Alibraheim \& Fowler, 2019). As a result, most researchers have been restricted to labeling students' attitudes as having positive, neutral, or negative attitudes toward mathematics without going deeper into knowing the causes that shape and produce these attitudes (e.g., Fennema \& Sherman, 1976; Tapia \& Marsh, 2004). Aiken's works $(1972,1974,1979)$ are considered one of the first works in this field, followed by the contributions of Fennema and Sherman (1976), Tapia and Marsh (2004), and Adelson and McCoach (2011). For instance, Aiken (1974) conducted a study to develop an instrument that measured the attitudes of 185 new students who enrolled at one college in the United States of America. Aiken included an instrument consisting of two subscales and examined students' attitudes toward mathematics, which were (1) the value of mathematics and (2) the enjoyment of mathematics. The most popular scale in this field, according to the words of Tapia and Marsh (2004), was Fennema Sherman Mathematics Attitude Scales. Fennema and Sherman (1976) surveyed 1,600 high school students to investigate the differences between males and females in their attitudes towards mathematics. Their instrument included nine factors that form student attitudes and also influence their academic achievement, which were (1) attitude toward success in mathematics, (2) mathematics as a male domain, (3) father subscale, (4) mother subscale, (5) teacher factor, (6) confidence in learning mathematics, (7) mathematics anxiety, (8) effectance motivation, and (9) usefulness of mathematics. A third example of researchers' contributions in this field is the Attitude Toward Mathematics Inventory (ATMI) by Tapia and Marsh (2004). Tapia and Marsh (2004) administered the ATMI to 545 high school students in the United States of America and concluded a scale with 49 items. These items test six factors that shape student attitudes: (1) self- confidence, (2) anxiety, (3) value, (4) enjoyment, (5) motivation, and (6) parent/teacher expectations.

Although it is useful to measure the attitude of students toward mathematics, the most important part is to study why these attitudes occur. This will help families, teachers and educators to enhance and develop the attitudes of their students. In addition, most of the previous studies that studied the variables impacting students' attitudes toward mathematics were done in western countries (Alibraheim, 2020; Huang \& Lin, 2015). Therefore, it is necessary to investigate the causes of students' attitudes in different countries, such as Saudi Arabia. Thus, this study attempts to obtain data that will help to address this issue by investigating the causes of the freshmen engineering students' attitudes toward mathematics using a qualitative research design. Specifically, the purpose of this study is to respond to the following research questions:

1. What are the freshmen engineering students' attitudes toward mathematics at Imam Abdulrahman Bin Faisal University (IAU) in Saudi Arabia?

2. Why do the freshmen engineering students have positive or negative attitudes toward mathematics at IAU?

\section{THEORETICAL \& CONCEPTUAL FRAMEWORK AND LITERATURE REVIEW}

\section{Attitude Toward Mathematics}

Early research on emotional aspects showed the significance of the interaction between attitudes and academic achievement. In further research, Bramlett (2007) stated that in 1926 Thurston contributed to the focus on the emotional factors like attitude, and its impact on other educational factors. Attitude is an essential part of human life; whether people love, hate, like, or dislike something is a response to their surroundings. Maio and Haddock (2014) mentioned that attitude refers to the feeling of satisfaction or discomfort, love or hate, and support or rejection of a particular thing. Hart (1989) defined attitudes as a favourable or an unfavourable reaction toward a given person, subject, idea, or person. Al Sheikh (1992) described attitude as a 
psychological and neurological readiness to act in a certain way toward a given subject. Similarly, Sarmah and Puri (2014) stated that attitude is an individual's positive or negative response to a situation, concept, or object. The last two studies considered attitudes as a measure of the reaction towards a certain subject. Way and Relich (1993) observed that although there is a difference in the definitions of the attitude, these definitions confirm that the attitude is the result of the individual's response to a specific topic or action, which means that the attitude can be measured as positive or negative.

There is growing recognition in educational research that attitude has a significant impact on learning mathematics. Neale (1969) underlined that the attitudes of students toward mathematics cause students to learn mathematics more. Thus, the attitudes of students towards mathematics determine the number of times students try to learn mathematics and how much fun they are having while learning mathematics (Moenikia \& Zahed-Babelanb, 2010). Ernest (2003) explained how a positive attitude leads to success. Students' success in mathematics will increase their positive attitude, which will lead them to work harder, whereas negative attitudes have the opposite effect.

The theoretical framework of this study is based on Neale's (1969) conceptualization of attitudes toward mathematics. According to Neale (1969), perceived attitudes toward mathematics refers to "a liking or disliking of mathematics, a tendency to engage in or avoid mathematical activity, a belief that one is good or bad at mathematics, and a belief that mathematics is useful or useless" (p. 3).

It also relied on the conceptual framework for theories that dealt with attitudes, such as the cognitive consistency theories Which believes that the individual seeks consistency between his attitudes and his behavior, and the alignment of trends with his behavior so that it appears rational, In the event that there is a contradiction between attitudes and behavior, the individual begins to re-balance so that the attitudes and behavior are consistent by changing attitudes or behavior (Santos, 1976).

The component theory for attitude which see that there are three components of the attitude, which are: the cognitive component that includes information and experiences that the individual is exposed to and will affect his view on a topic, the emotional component that refers to the emotional aspects that affect the individual's acceptance or rejection of something. The behavioral component refers to the work performed by the individual, as it is a practical translation of the individual's attitudes towards things, people or ideas. It is helpful in understanding the potential relationship between attitudes and behavior (Jain, 2014).

\section{The Impact of Attitudes Toward Mathematics}

The failure of mathematics is a global problem that many students face coming from various disciplines and numerous countries. Many studies over time have tried to find the causes of this problem in order to address or reduce its effects (Jameel \& Ali, 2016; Jega, Muhammad, \& Gwandu, 2018; Michael, 2015). One of the main reasons for this phenomenon is students' attitudes toward mathematics; positive or negative attitudes have a clear impact on the students' performance and grades in the subject. It is well understood that the attitudes of students toward a topic can influence their academic performance (Popham, 2005). Karjanto (2017) studied the attitudes of 108 students enrolled in the Foundation Year Program at a university in Kazakhstan and found that most students had positive attitudes and their attitudes were affected by their grades in the mathematics test. Students with high grades in the test had positive relationships with their attitudes toward mathematics. In addition, the attitudes of students should be important to teachers, because students' affective dispositions are strong predictors of their actions and achievement (Popham, 2005; Suydam \& Weaver, 1975; Tapia \& Marsh, 2004).

Many studies confirm the difficulties of freshmen engineering students with regards to their performance in mathematics (e.g., Harris et al, 2015; Mwavita, 2005; Parsons, 2004; Prakash et al., 2014). Mwavita (2005) tested the variables that predict calculus success among 512 freshmen engineering students in the United States. The predictor variables were high school GPAs, the score of American College Testing (ACT) for mathematics, ACT composition, and the total number of mathematics courses taken at the junior and senior high school level. The researcher concluded that many of the students failed to earn a grade of A, B, or C in calculus courses. Prakash et al. (2014) investigated the reasons for the failure of engineering students in mathematics. The researchers studied engineering students enrolled in 570 engineering colleges in India. They found that one of the important causes for the failure of engineering students in mathematics is the fact that they considered mathematics a difficult subject since childhood. Harris et al (2015) interviewed professors and freshmen engineering students who had problems with mathematics in order to identify the cause of their problems. Researchers confirmed that mathematics is still the central problem for freshmen engineering students, and universities should consider redesigning the mathematical curriculum for engineering students.

There are many additional studies dealing with the attitudes of freshmen engineering students and their significant impact on performance in mathematics. Syam and Salim (2014) studied the reasons for the reduction of the number of students who study mathematics in many Gulf universities and especially at Qatar University. The researchers stated that students' attitudes toward 
mathematics influenced their performance and their success in the subject, which led students to avoid mathematics. Eng et al. (2010) tested the factors that influenced the mathematics grades of 1,050 college students in Malaysia. They illustrated that the positive attitudes of students may increase achievement and negative attitudes may decrease achievement in mathematics. In contrast, Huang (2011) investigated the Taiwanese engineering students' attitudes toward calculus and concluded that most students did not have positive attitudes, which caused them to receive low grades in calculus. Additionally, Nahari (2014) investigated the mathematics skills and attitudes of all freshmen engineering students in Dublin City University. The findings of this study showed positive motivation and good attitudes toward mathematics among all students. The researcher emphasized that it is necessary to study the attitudes of freshmen engineering students toward mathematics in the beginning and in the end of the semester, in order to have a better understanding of how it affects their achievement and academic performance. Furthermore, Shaw and Shaw (1999) surveyed UK engineering students at three different universities to discover the variables that contribute to the formation of their attitudes towards mathematics. Their findings showed that students' preuniversity experience, university experience and the perceived workload at the university were determined by their attitudes.

\section{Reasons for Students' Attitudes Toward Mathematics}

Even though it is necessary to study the attitude of students because there is a correlational relationship between their attitude toward mathematics and their mathematical performance, the more important aspects to investigate are the factors and reasons that shape their attitude. It will thereby help parents and teachers to encourage positive attitudes in their students, which will influence their results in mathematics. Mazana, Montero, and Casmir (2019) examined the causes affecting students' attitudes towards mathematics in Tanzania. Their sample consisted of 869 students at the primary, secondary, and university levels. The researchers concluded that Tanzanian students had positive attitudes towards mathematics, and the reasons for these attitudes were: (1) feeling joy when learning mathematics, (2) academic competence of the student, (3) teaching methods, (4) classroom educational environment, (5) availability of scientific means in the school, and (6) tests results. Several studies indicate the influence of other factors such as colleagues and friends (He, 2007; Yang, 2013), family and parents (Davadas \& Lay, 2020), school (Laguador \& Dotong, 2020; Yang, 2013), teachers' personal characteristics (Al Shabibi, Al Mantheri, \& Al Rashdi, 2019; Blazar \& Kraft, 2017; Sakiz, Pape, \& Hoy, 2012), teachers' knowledge of content (Simmers, 2011), language (Mazana, Montero, \& Casmir,
2019), and how mathematics relates to daily life (Y1lmaz, Altun, \& Olkun, 2010).

Previous studies showed a set of factors that affect students' attitudes toward mathematics. These factors are considered theoretical foundations on which this study depends for the exploration of the factors affecting the attitudes of freshman engineering students in Saudi Arabia.

\section{MATERIALS AND METHODS}

\section{Research Design}

This study employed a qualitative design to answer the research questions. Interviews were used to collect the qualitative data from participants. According to Gallo (2014), interview questions help the researcher to achieve deeper understanding of the phenomenon or problem of the study. Therefore, this design gave the researcher the opportunity to deeply understand the causes and factors that formulated freshman engineering students' attitudes toward mathematics.

\section{Participants}

Overall, 26 freshmen male engineering students enrolled in the engineering program in Fall 2018 at Imam Abdulrahman Bin Faisal University (IAU) in Saudi Arabia participated in this study. To eliminate selection bias, the participants were randomly selected through five mathematics courses offered at the beginning of their engineering program, and each one of the participants had the freedom to decline participation in this study.

\section{Data Sources and Procedures}

Qualitative data was collected from 26 participants. These participants were asked two open-ended questions in a face-to-face interview to understand their attitudes towards mathematics and explore the factors that shaped these attitudes. The first question asked, "What is the freshmen engineering students' attitude toward mathematics at Imam Abdulrahman Bin Faisal University (IAU) in Saudi Arabia?". The second question asked, "Why do the freshmen engineering students have positive or negative attitudes toward mathematics at IAU?" During the interview, the researcher encouraged the students to give detailed answers. Participants were informed about the goals of the study and that their answers and information were confidential. After the researcher received the approval to collect the data from the Institutional Review Board (IRB) at IAU, participants were interviewed with each interview taking 10 minutes to complete. Participants' responses to the interview questions helped to obtain deep and detailed explanations about their attitudes toward mathematics. Participants had an opportunity to share their opinions, feelings, and attitudes toward mathematics. The 
researcher coded and examined the recorded responses. All the responses were organized based on the question number and then presented to two other researchers to review and validate the responses.

\section{Data Analysis}

Thematic content analysis was used to analyze the interviews. This kind of analysis helps researchers to eliminate biases and to create overarching impressions of the interview data through finding common patterns across the participants' responses (Pierre \& Jackson, 2014). To analyze the data, the researcher followed the following steps. In the first phase, the audio recordings were transcribed into written texts to make it easier for the researcher to read and identify the details of the audio data. In the second phase, codes were assigned to the information in the data by organizing it into a matrix of open coding. In the third phase, some similar or sub themes were combined to form broader themes. In the fourth phase, all themes were read and reviewed in order to distinguish coherent and distinctive themes. In the fifth phase, all the themes were named and defined based on the essential idea of the theme. In the final phase, the results were written using participants' direct quotes.

\section{RESULTS}

The researcher contacted the students for an openended interview. After three rounds of attempts to convince the students to participate, 26 of the freshman engineering students agreed to meet and answer the interview questions. All the participants were over 18 years old and enrolled at Imam Abdulrahman Bin Faisal University (IAU). Audio recording was used to save each interview in order to help the researcher analyze the data. Fictional names were used when referencing students. Any quotes that were recorded in this study regarding the results of the interviews were taken verbatim from the audio recording in order to provide the reader with the most accurate answer from each student. The researcher created a matrix of open coding from keywords attached to each answer from the interviewees. The matrix contains 26 rows to represent the participants, and two columns to represent the questions in the interview. Additionally, in order to establish credibility, the analyzed interview data was reviewed by two professors from Saudi Arabia, who recommended minor amendments. All their recommendations were taken into consideration.

\section{Interview Questions: Factors and Current Attitude}

The interview discussions helped the researcher to explore the students' ideas about the survey questions in greater depth. Analysis of the responses to the first and second interview questions revealed that all students had either positive or neutral attitudes toward mathematics. $58 \%$ of the participants showed positive attitudes, and $42 \%$ of them showed neutral attitudes. The reasons for their positive attitudes included three major themes: (1) teacher's positive characteristics, (2) parental support, (3) practice and preparation. One student answered that his teacher had the strongest impact on his attitude toward mathematics. He was very glad that his high school mathematics teacher was "patient and helpful and always used a joke in teaching" (Anwar G., personal interview, October 3, 2018).

At the same time, the reasons for their neutral attitudes involved four major themes: (1) teacher's negative characteristics, (2) assessments and grades, (3) effect of English proficiency, and (4) time management. Some participants answered that exam grades were one major reason why they were afraid of mathematics. One of them confirmed that he used to love mathematics and complained that mathematics assessments caused him to waste his time and effort in high school (Jafar A., personal interview, October 3, 2018). Figure 1 and Figure 2 show the justification of the opinions provided by the participants based on their attitudes.

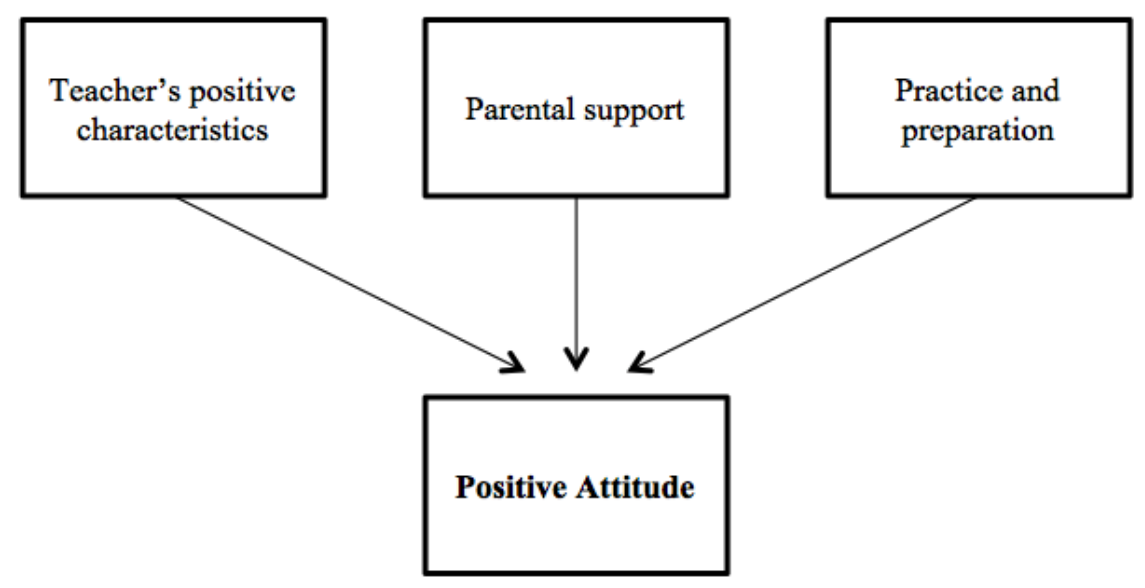

Figure 1. Themes and factors that contribute to the positive attitude 


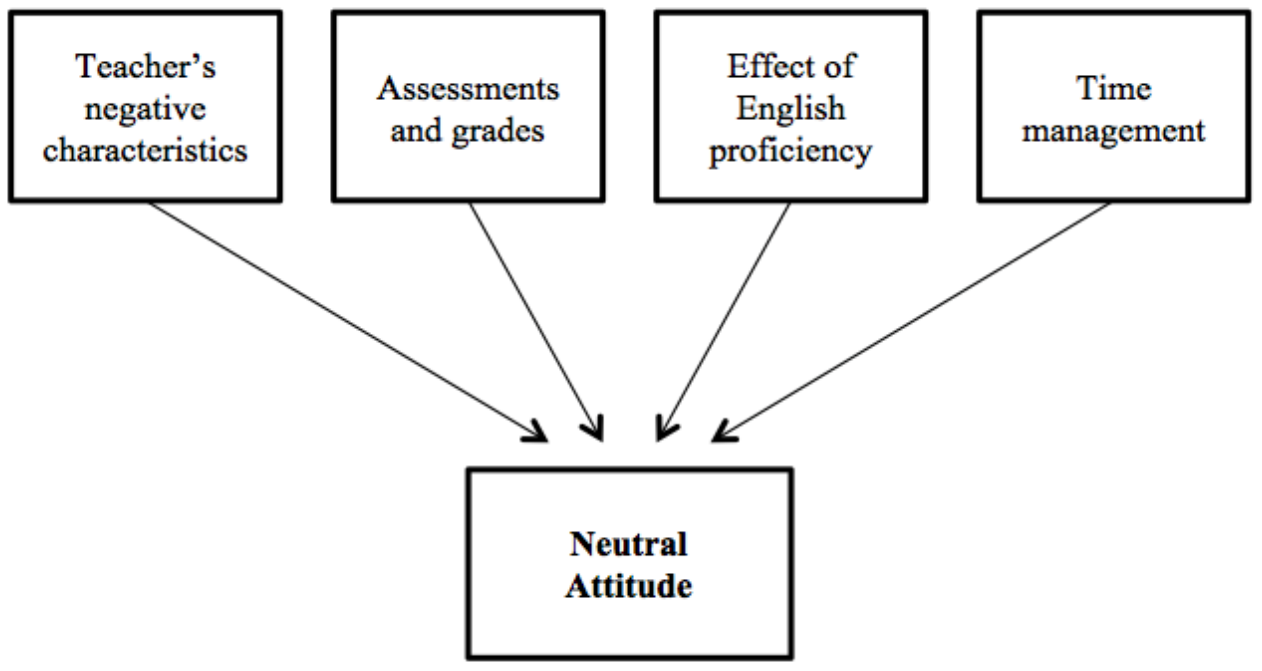

Figure 2. Themes and factors that contribute to the neutral attitude

\section{Factors leading to a positive attitude}

Teacher's positive characteristics. This factor has shed light on how students believe their attitudes toward mathematics are shaped, and who they feel forms their attitudes. 13 participants mentioned that teacher characteristics had a strong influence on their attitudes toward mathematics. They indicated that their attitudes toward mathematics could change with different teachers. Student comments used some personal characteristics of the teacher (nice, strict, funny, willing to help, caring) to illustrate how these characteristics increase their positive attitudes. For example, Mohammed had always struggled with mathematics in elementary school and felt his middle school mathematics teacher played a major role in his positive attitude.

Mohammed stated that:

I thought I never understood mathematics when I was in elementary school, until I met a nice math teacher in middle school who changed my mind and made me feel that I could learn. The first time I got the full mark in a mathematics exam was in his class. He was credited with my love of mathematics and my trust in myself (Mohammed A., personal interview, September 12, 2018).

Also, Sultan recalled his experience with his mathematics teachers, and explained how his mathematics attitude has been changed because of his teachers.

\section{Sultan said:}

In elementary school, I loved mathematics because I had a teacher that really tried to make me understand it. His class was so fun and active. But, in middle school, I had a boring teacher who taught me for three years. He just stood at the board and kept writing, and at the end of the class he gave us many questions for homework. I hate mathematics because of him. Fortunately, my mathematics teachers in high school were really helpful. I was so lucky they were very supportive for the whole year. They always opened the discussion, listened to my questions, and were patient with my mistakes. I can't work when the teachers are not nice. It is very difficult (Sultan W., personal interview, November 29, 2018).

Parental support. The second major reason for the positive attitudes of freshman engineering students toward mathematics was parental support. Nine participants explained that parents, especially fathers, had a direct influence on their love of mathematics. The father's discussion with his children and showing how much he liked mathematics had a great impact on the children's attitudes. One student claimed that his father had to quit school because of physical conditions, however, he always shows his love and knowledge of mathematics. His father has remembered a multiplication table up to 99 . So, the student believes that his love for mathematics was influenced by his father's love of the subject (Anwar G., personal interview, October 3, 2018). The influence of the father's work and his practice of mathematics also reflected on his children because this influence appeared in his daily life.

One participant mentioned that,

My father is an engineer and he always uses mathematics even at home. Guess what? He has written the value of $\pi$ on the wall of our living room. I dream of being an engineer like my father and using mathematics everywhere (Mustafa A., personal interview, September 17, 2018). 
Practice and preparation. Seven participants agreed that continuous training in solving mathematics problems and having sufficient time to study the subject were important elements in their confidence in their mathematics abilities and caused an improvement in their positive attitudes. Jafar stated that mathematics is a subject that needs paper and pencil. When you are given enough time to solve many different ideas for a concept, it gives you a sense of comfort and joy (Jafar A., personal interview, October 3, 2018). Jafar's thought was supported by his colleague Ali. Ali claimed that spending enough time practicing and solving mathematical problems, even if the problems were easy, would make you feel that you will be able to solve the difficult ones as well. This leads you to accept mathematics and not to fear it (Ali M., personal interview, October 10, 2018).

\section{Factors leading to a neutral attitude}

Teacher's negative characteristics. Eleven participants discussed negative characteristics of teachers that they felt affected their attitudes toward mathematics, such as being boring, angry, impatient, and frustrated. They believed that the teachers' negative characteristics were the most important factor in their neutral attitude toward the subject. Seven of the 11 students who had neutral attitudes focused on the personal demeanor of the teacher and how it impacted their attitudes. One participant stated, "I began to hate class time because the teacher was always angry. $\mathrm{He}$ could not bear to see a student who did not understand the lesson" (Abdullah R., personal interview, October 9, 2018). Nine of the 11 students who had neutral attitudes emphasized the professional demeanor of the teacher. One of the participants stated, "My teacher did not help me learn mathematics correctly. He had used simple examples in class, but he had written hard questions on the test. Truly, I do not know where his questions came from" (Waleed S., personal interview, September 26, 2018).

In addition, the importance of the interaction and relationship between the teachers and their students was one of the main points that was mentioned by five of the 11 students who had neutral attitudes. The students felt that relaxed interactions with the teacher had more impact on their attitudes than other factors.

As one student discussed that:

I remember how my high school mathematics teacher thought that the only subject we were studying was mathematics. When we tried to tell him that we have tasks in other subjects, he would just get mad and give our class more homework. Just think, he gave us more homework every Thursday because we had the weekend. He never respected or felt for us (Faisal R., personal interview, October 15, 2018).
Assessments and grades. Nine participants expressed that the grades on the mathematics test were the cause of their current neutral attitude toward mathematics. Mathematics has the greatest weight in an engineering major; therefore, low grades in mathematics courses affect the student's academic GPA. Abdullah, along with Muslim and Nayef, conveyed this feeling. When Abdullah was asked to describe his current attitude toward mathematics, he said, "I really would like to say it is positive but my grades in my mathematics exam makes me say it's a neutral attitude" (Abdullah R., personal interview, October 9, 2018). Similarly, Mohammed said, "my attitude is neutral not because of the subject but because of my grades in mathematics" (Muslim A., personal interview, September 12, 2018). Nayef echoed their thoughts when talking about his attitude toward mathematics.

I do not hate mathematics but I also do not love it. When I solve mathematics problems at home, I feel it is the most beautiful subject. I can see the developing of my abilities. However, when the time of the test comes, I feel it is a little hard to remember what I learned. It makes me lose some points on the test, which affects my GPA (Nayef O., personal interview, October 10, 2018).

This shows that engineering students are under pressure to maintain good grades in mathematics.

English language effect. The educational system in the Kingdom of Saudi Arabia uses the Arabic language for teaching all subjects, except English. Students use the Arabic language from elementary to high school in all schools that follow the Saudi system, regardless of whether they are public or private. International schools, in some cities of Saudi Arabia, have a different structure because they follow the system of the countries that they originated in and use their curricula. Most Saudi students graduate from Saudi schools. The Arabic language is the language of instruction from Grades 1 through 12. Many students indicated that language barriers created more problems in mathematics at the university level. Students spent most of their time studying the English mathematical vocabulary instead of studying the mathematical concepts. Ten students agreed that English was an obstacle for understanding of mathematics.

One of them stated:

I spend a lot of time studying mathematics because I do not understand what the professor says in the lecture. He uses English and speaks very fast. I feel disappointed. I cannot ask any questions during the class because I did not understand what he was saying (Saud T., personal interview, October 11, 2018). 
Some students indicated that studying mathematics in Arabic would be easier. Abdulrahman said, "I wish I could study mathematics in Arabic. I would not lose some points on the test because I did not understand the question" (Abdulrahman T., personal interview, October 3, 2018).

Time management. Undergraduate students must take many courses at the same time in one semester of university, which is one of the challenges that new students face. Learning time management skills is one of the most important skills that many universities seek to develop in their students. Eight students explained that they do not designate enough time to mathematics because there are many courses they have to study for.

One student said:

Actually, I don't practice enough mathematical problems because I leave my college at $5 \mathrm{pm}$ everyday, and I have many other tasks in different courses that I have to finish. I do not find enough time to sit with my family, so how can I find enough time to solve many mathematical exercises? (Rashed M., personal interview, October 9, 2018).

Another student believed that the pressure of other courses affected his understanding of mathematics. Every professor considers their subject to be the most important subject. Thus, professors compete by giving many tasks and homework assignments to solve, and this affects students' learning in mathematics (Salman N., personal interview, October 5, 2018).

\section{DISCUSSION}

The purpose of the current study was to investigate the factors that affect freshman engineering students' attitudes toward mathematics using a qualitative research design. The results of the interview showed that $58 \%$ of the participants had a positive attitude towards mathematics, while $42 \%$ had a neutral attitude. Therefore, in general, new engineering students at IAU have shown a positive attitude towards mathematics.

Participants identified three main reasons for their positive attitudes, namely the positive characteristics of the teacher, parental support, and practice and preparation. The remaining students identified four main reasons for their neutral attitudes, namely the negative characteristics of teachers, their assessments and grades, the influence of the English language, and time management. Regarding parental support, participants focused more on the influence of their fathers. According to one of the participants in the interview, his father's engineering work had a major impact on his desire to study engineering and also in mathematics. This finding emphasizes the impact of the parents' professional attitudes on their children's attitudes toward mathematics. This finding is supported by other studies' results that also showed there was a positive correlation between parents' career type and their children's achievement (Checchi, 2000; Dahl \& Lochner, 2012). Checchi (2000) focused on the reasons for the low educational achievement of university students in Italy. The results showed that there was a positive correlation between family income and students' achievement; parents who had a higher income provided an incentive for better academic performance.

However, other studies contradicted the results because they had a neutral or a negative relationship towards mathematics (Akhtar, 2012; Camello, 2014; Hijazi \& Naqvi, 2006). Hijazi and Naqvi (2006) studied the factors that affect college students' performance in Pakistan. The researchers found that there was a negative relationship between the parents' career type and their children's performance. Students from affluent families did not work as hard in school as poorer students. However, the analysis of the current study's data shows that in Saudi Arabia, parents' work, especially in the engineering field, had a significant impact on students' positive attitudes. This means that the extent to which the parents' work is related to their children's majors or the extent to which it is related to mathematics may affect their children's attitudes toward mathematics.

Many participants noted that teachers' positive or negative characteristics influenced their attitudes toward mathematics. Participants used vocabulary that included the characteristics gentle, cooperative, nervous, or boring to describe their teachers. Positive characteristics were associated with an increase in students' positive attitudes, and negative characteristics associated with a decrease in students' positive attitudes. In addition, some participants reported the effect of parental support on increasing their positive attitudes. They thought that parents, especially their fathers, had a direct impact on their love of mathematics. These findings are supported by other studies' results that also mentioned the impact of teachers and parents on students' attitudes (e.g., Areepattamannil et al., 2015; Gegbe, Sundai, \& Sheriff, 2015; Mohr-Schroeder et al., 2017). This result proves that if students love their teachers or think their teachers are good, this will affect their motivation to learn and increase their effort when learning the subject.

The amount of practice by students when solving mathematical problems was no less important in shaping student attitudes toward mathematics. Most participants stated that spending enough time to solve math problems properly made them trust in their mathematical abilities and improve their attitude. Moreover, many participants expressed that low scores on mathematics exams and the inability to allocate and manage time to study mathematics and other subjects were important reasons for reducing their positive attitudes toward mathematics. The study of Ignacio, 
Nieto, and Barona (2006) supports this finding as it was found that good results on the test are significant motivation for students' love of mathematics. A good score on a test improved and increased students' confidence in themselves and in learning the subject.

The current study also revealed that students' weaknesses in the English language and lack of understanding of what the professor was saying in the lecture were two reasons for reducing their positive attitudes. This is similar to the finding by Neville-Barton and Barton (2005); Mazana et al. (2019); and Yonson (2017). Mazana et al. (2019) found that the biggest problem that non-native English students faced in mathematical learning was difficulty with the language. Students struggled to decipher the information presented to them in English instead of understanding the mathematical content. In the current study, it was found that participants would have liked to have a course in which they could learn English terminology related to mathematics in order to facilitate their understanding of mathematics courses that are taught in English.

In an in-depth look at the reasons mentioned by the participants, the observer can see that the reasons are either internal, depending on the students themselves, or external, depending on factors around the students. Internal causes include training and preparation, assessments and grades, effect of English proficiency, and time management. External causes include teacher characteristics and parental support. Ratings and grades usually depend on the time students spend studying materials and practicing various math problems. The influence of the English language also depends on students' attempts to develop their language skills. Consequently, it is possible to find that the internal causes are more numerous than the external causes in relation to attitudes towards mathematics.

The results of the current study proposes a conceptual framework about factors that affect freshman engineering students' attitudes toward mathematics; As shown in the Figure 3.

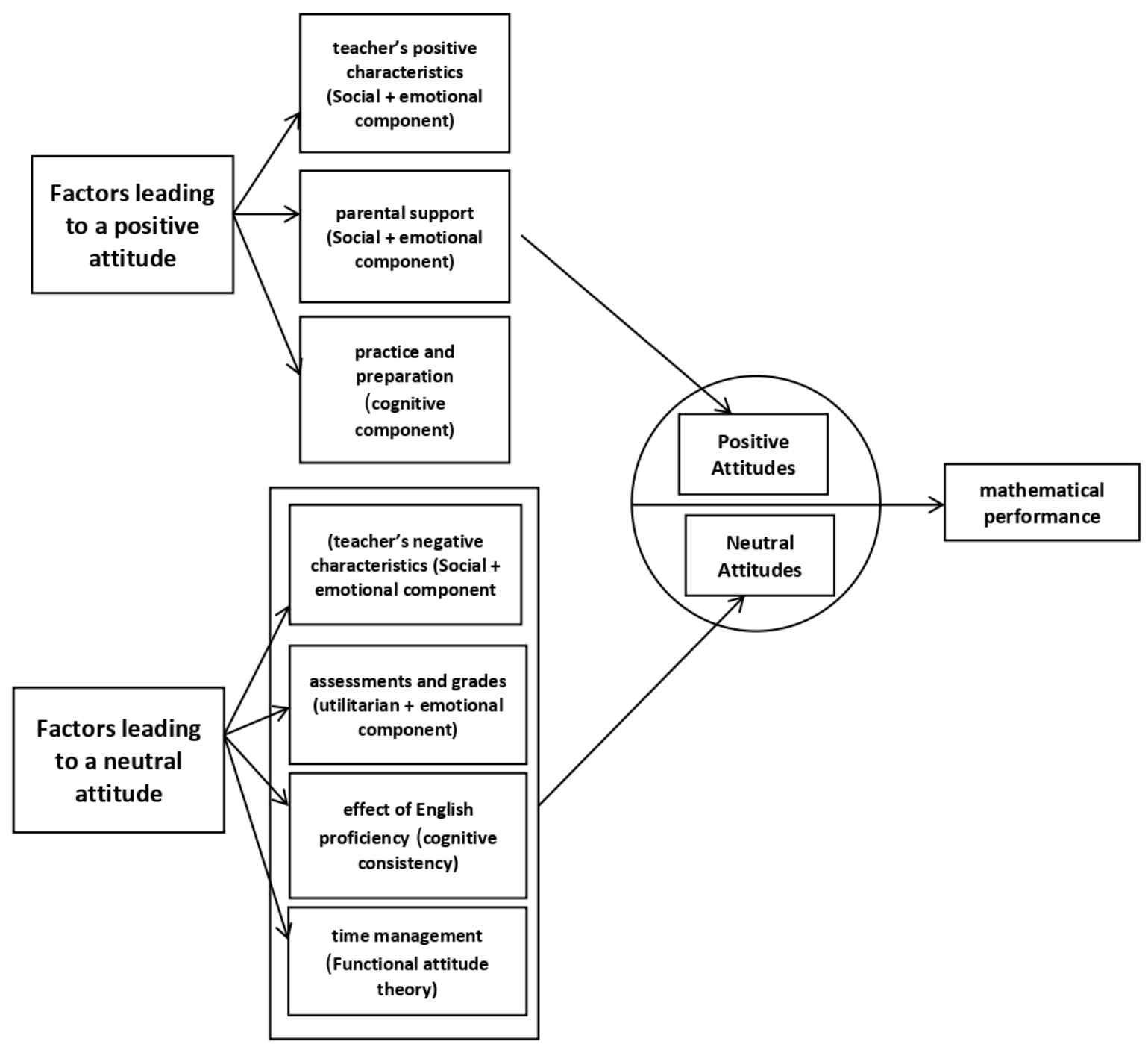

Figure 3. A conceptual framework about factors that affect freshman engineering students' attitudes toward mathematics 


\section{CONCLUSION}

The purpose of this study was to investigate the factors that affect freshman engineering students' attitudes toward mathematics using a qualitative research design. Findings from the study indicate that IAU freshman engineering students have positive attitudes toward mathematics, and their attitudes are more affected by their fathers and their teachers. The results of the interviews indicated that the reasons that participants considered in shaping their attitudes towards mathematics can be divided into two parts internal reasons resulting from the students themselves and external reasons resulting from others. The internal reasons are (1) practice and preparation, (2) assessments and grades, (3) English language effect, and (4) time management. The external reasons are (1) teachers' characteristics and (2) parental support. Spending more time in practice and training to solve different ideas of mathematical concepts increased the probability of obtaining high grades on mathematics tests. Earning high grades in mathematics increased positive attitudes towards mathematics. Therefore, most factors that affect students' attitudes came from the students, so the solutions should be aimed at the students as well. As a result, the present study confirms that the majority of the reasons that affect freshman engineering students' attitudes stem from the students themselves.

This study recommends that teachers should pay attention to their personal attitudes when in class because students are influenced by their teachers' behavior and words. The words and behaviors demonstrated by the teacher in the classroom affect the students' motivation to learn. Teachers should choose stimulating vocabulary when supporting their students and try to curb their anger because it has a negative effect on students' learning. Supporting students and trying to encourage them to learn, whether verbally or physically, will improve students' attitudes and increase their academic achievement. Furthermore, students must learn how to organize their time and practice solving a variety of mathematical problems to understand and master mathematical concepts. They should be taught useful strategies for learning and taking exams. Students also need to improve their language skills. Including mathematical terms in English taught in schools of all levels will help increase students' mastery of English, which in turn will increase their academic achievement in mathematics.

Furthermore, learners should continuously be offered an opportunity to share their thoughts and worries about mathematics teaching and learning. Students' feedback can be used to improve their attitudes toward mathematics and to meet their learning needs.

This study may help the Saudi Ministry of Education, other researchers, administrators, and faculty members to have a better understanding of the freshman engineering students' attitudes and the factors that shape their views. This may allow them to create programs that would better serve the engineering students to be academically successful.

Funding: No funding source is reported for this study.

Declaration of interest: No conflict of interest is declared by the author.

\section{REFERENCES}

Adelson, J. L., \& McCoach, D. B. (2011). Development and psychometric properties of the math and me survey: Measuring third through sixth graders' attitudes toward mathematics. Measurement and Evaluation in Counseling and Development, 44(4), 225247. https:/ / doi.org/10.1177/0748175611418522

Aiken, L. (1972). Research on attitudes toward mathematics. The Arithmetic Teacher, 19(3), 229-234. https://doi.org/10.5951/AT.19.3.0229

Aiken, L. (1974). Two scales of attitude toward mathematics. Journal of Research in Mathematics Education, 5(2), 67-71. https://doi.org/10.2307/ 748616

Aiken, L. (1979). Attitudes toward mathematics and science in Iranian middle schools. School Science and Mathematics, 79, 229-234. https:/ / doi.org/10.1111/ j.1949-8594.1979. tb09490.x

Akhtar, Z. (2012). Socio-economic status factors effecting the students achievement: A predictive study. International Journal of Social Sciences and Education, 2(1), 281-287. https:// citeseerx.ist.psu.edu/ viewdoc/download?doi=10.1.1.1045.5166\&rep=re p1\&type=pdf

Al Shabibi, A., Al Mantheri, A., \& Al Rashdi, B. (2019). Impact of teacher professional development on student attitudes and experiences in school learning - A case study of oman. International Journal of Learning, Teaching and Educational Research, 18(10), 48-67. https://doi.org/10.26803/ ijlter.18.10.4

Al Shaikh, A. (1992). Social psychology. Anglo-Egyptian Library.

Alibraheim, E. (2020). Investigating the attitudes toward mathematics for the saudi scholarship students in the united states. The International Journal of Science, Mathematics and Technology Learning, 27(2), 35-50. https:/ / doi.org/10.18848/23277971/CGP/v27i02/35-50

Alibraheim, E., \& Fowler, S. (2019). Examining the gender differences among saudi scholarship students' attitudes toward mathematics in the united states. The International Journal of Humanities Education, 17(2), 57-65. https://doi.org/10.18848/ 2327-0063/CGP/v17i02/57-65 
Areepattamannil, S., Khine, M., Melkonian, M., Welch, A., Al Nuaimi, S., \& Rashad, F. (2015). International note: Are emirati parents' attitudes toward mathematics linked to their adolescent children's attitudes toward mathematics and mathematics achievement?. Journal of Adolescence, 44(2), 17-20. https://doi.org/10.1016/j.adolescence.2015.07.002

Blazar, D., \& Kraft, M. (2017). Teacher and teaching effects on students' attitudes and behaviors. Educational Evaluation and Policy Analysis, 39(1), 146170. https:/ / doi.org/10.3102/0162373716670260

Bramlett, D. (2007). A study of african-american college students' attitudes towards mathematics (Unpublished Ph.D dissertation). Center for Science and Math Education: University of Southern Mississippi. https:/ / aquila.usm.edu/dissertations/1299

Camello, N. (2014). Factors affecting the engineering students' performance in the OBE assessment examination in mathematics. International Journal of Academic Research in Progressive Education and Development, 3(2), 87-103. https:/ / doi.org/10.6007/IJARPED/v3-i2/913

Checchi, D. (2000). University education in italy. International Journal of Manpower, 21(3/4), 177-205. https://doi.org/10.1108/01437720010335969

Dahl, G., \& Lochner, L. (2012). The impact of family income on child achievement: evidence from the earned income tax credit. The American Economic Review, 102(5), 1927-1956. https://doi.org/10.1257 /aer.102.5.1927

Davadas, S., \& Lay, Y. (2020). Contributing factors of secondary students' attitude towards mathematics. European Journal of Educational Research, 9(2), 489498. https:/ / doi.org/10.12973/eu-jer.9.2.489

Eng, T. H., Li, V. L., \& Julaihi, N. H. (2010). The relationships between students' underachievement in mathematics courses and influencing factors. Procedia-Social and Behavioral Sciences, 8, 134-141. https:// doi.org/10.1016/j.sbspro.2010.12.019

Ernest, P. (2003). Setting the scene: the mathematical attitudes, beliefs and ability of students. Maths for Engineering and Sciences, 4-5. https:/ / studylib.net/ doc/13483782/maths-for-engineering-and-science

Fennema, E., \& Sherman, J. A. (1976). Fennema-sherman mathematics attitudes scales: instruments designed to measure attitudes toward the learning of mathematics by females and males. Journal for Research in Mathematics Education, 7(5), 324-326.

Gegbe, B., Sundai, A., \& Sheriff, V. (2015). Factors contributing to students poor performance in mathematics at west african senior school certification examination (a case study: Kenema city, eastern province sierra leone). International Journal of Engineering Research and General Science,
3(2), 1040-1055. http:/ / pnrsolution.org/Datacenter /Vol3/Issue2/147.pdf

Goodykoontz, E. N. (2008). Factors that affect college students' attitude toward mathematics (Unpublished Ed.D dissertation). Morgantown, WV: College of Human Resources and Education at West Virginia University. https://researchrepository.wvu.edu/ cgi / viewcontent.cgi? article $=3841 \&$ context $=$ etd

Goold, E. (2012). The role of mathematics in engineering practice and in the formation of engineers (Unpublished Ph.D dissertation). Department of Design Innovation: National University of Ireland Maynooth. http://mural.maynoothuniversity.ie/ 4766/1/PhD\%20THESIS\%20-\%20VOLUME\% 201$\%$ 20Eileen \%20Goold.pdf

Harris, D., Black, L., Hernandez-Martinez, P., Pepin, B., Williams, J., \& with the TransMaths Team. (2015). Mathematics and its value for engineering students: what are the implications for teaching? International Journal of Mathematical Education in Science and Technology, 46(3), 321-336. https:/ / doi.org/10.1080/0020739X.2014.979893

Hart, L. (1989). Classroom processes, sex of student, and confidence in learning mathematics. Journal for Research in Mathematics Education, 20(3), 242-260. https:/ / doi.org/10.2307/749514

Hijazi, S., \& Naqvi, R. (2006). Factors affecting students' performance. Bangladesh E-Journal of Sociology, 3(1), 10. https://www.researchgate.net/profile/ Sayyed_Naqvi/publication/281060722_FACTORS _AFFECTING_STUDENTS'_PERFORMANCE_A_ Case_Of_Private_Colleges/links/55d2dbd508aec1 b0429efad3/FACTORS-AFFECTING-STUDENTSPERFORMANCE-A-Case-Of-Private-Colleges.pdf

Huang, C. (2011). Investigating the attitudes toward calculus of engineering students in taiwan. World Transactions on Engineering and Technology Education, 9(2), 80-85. http:/ / www.wiete.com.au/ journals/WTE\%26TE/Pages/Vol.9,\%20No.2\%20(2 011)/03-Huang-CH.pdf

Huang, Y., \& Lin, S. (2015). Development and validation of an inventory for measuring student attitudes toward calculus. Measurement and Evaluation in Counseling and Development, 48(2), 109-123. https:/ / doi.org/10.1177/0748175614563314

Ignacio, N., Nieto, L., \& Barona, E. (2006). The affective domain in mathematics learning. International Electronic Journal of Mathematics Education, 1(1), 1631. http://www.iejme.com/download/theaffective-domain-in-mathematics-learning.pdf

Jain, V. (2014). 3D model of attitude. International Journal of Advanced Research in Management and Social Sciences, 3(3), 1-12. https:/ / garph.co.uk/IJARMSS/ Mar2014/1.pdf 
Jameel, H., \& Ali, H. (2016). Causes of poor performance in mathematics from teachers, parents and student's perspective. American Scientific Research Journal for Engineering, Technology, and Sciences, 15(1), 122-136. https://www.researchgate.net/ publication/306910423_Causes_of_Poor_Performa nce_in_Mathematics_from_Teachers_Parents_and _Student's_Perspective

Jega, S., Muhammad, S., \& Gwandu, Z. (2018). Causes of students mass failure in mathematics at senior secondary schools certificate examination (SSCE) in some selected secondary schools in kebbi state. International Journal of Education and Evaluation, 4(4), 12-25. https://iiardpub.org/get/IJEE/VOL.\%204 \%20NO.\%204\%202018/CAUSES\%20OF\%20STUD ENTS.pdf

Kafata, F., \& Mbetwa, S. (2016). An investigation into the failure rate in mathematics and science at grade twelve 12 examinations and its impact to the school of engineering: a case studyof kitwe district of zambia. International Journal of Scientific $\mathcal{E}$ Technology Research, 5(8), 71-93. https://doaj.org/ article/9995d7bf5cd84eba884b4be4813c60d0

Karjanto, N. (2017). Attitude toward mathematics among the students at nazarbayev university foundation year programme. International Journal of Mathematical Education in Science and Technology, 48(6), 849-863. https://doi.org/10.1080/0020739X. 2017.1285060

Laguador, J., \& Dotong, C. (2020). Engineering students' challenging learning experiences and their changing attitude towards academic performance. European Journal of Educational Research, 9(3), 11271140. https:/ / doi.org/10.12973/eu-jer.9.3.1127

Maio, G., \& Haddock, G. (2014). The psychology of attitudes and attitude change (2nd ed.). Sage Publications. https://doi.org/9781446272268

Mazana, M., Montero, C., \& Casmir, R. (2019). Investigating students' attitude towards learning mathematics. International Electronic Journal of Mathematics Education, 14(1), 207-231. https://doi.org/10.29333/iejme/3997

Michael, I. (2015). Factors learning to poor performance in mathematics subject in kibaha secondary schools. Master theses not published. Administration, Planning and Policy Studies (MED. APPS): The Open University of Tanzania. https:/ / core.ac.uk/ download/pdf/44684738.pdf

Moenikia, M., \& Zahed-Babelan, A. (2010). A study of simple and multiple relations between mathematics attitude, academic motivation and intelligence quotient with mathematics achievement. Procedia Social and Behavioural Sciences, 2, 1537-1542. https://doi.org/10.1016/ j.sbspro.2010.03.231
Mohr-Schroeder, M., Jackson, C., Cavalcanti, M., Jong, C., Schroeder, D., and Speler, L. (2017). Parents' attitudes toward mathematics and the influence on their students' attitudes toward mathematics: A quantitative study. School Science and Mathematics, 117(5), 214-222. https://doi.org/10.1111/ssm. 12225

Mwavita, M. (2005). Factors influencing calculus course success among freshmen engineering students. Ph.D. thesis not published. Educational Statistics and Research Methods: Oklahoma State University. Available from Dissertations \& Theses Europe Full Text: Social Sciences. https:// search.proquest.com /docview/305385022

Nahari, N. (2014). Mathematical skills and attitudes of first year engineering students (Unpublished Master thesis). School of Mathematical Studies: Dublin City University. http://doras.dcu.ie/20200/1/ ThesisNoha.pdf

Neale, D. (1969). The role of attitudes in learning mathematics. The Arithmetic Teacher, 16, 631-641. https://doi.org/10.5951/AT.16.8.0631

Neville-Barton, P., \& Barton, B. (2005). The Relationship between English Language and Mathematics Learning for Non-native Speakers. TLRI.

Parsons, S. (2004). Overcoming poor failure rates in mathematics for engineering students: a support perspective. Harper Adams University College, http:/ / citeseerx.ist.psu.edu/viewdoc/download? doi $=10 \cdot 1 \cdot 1 \cdot 567 \cdot 3249 \&$ rep $=$ rep1\&type $=$ pdf

Pierre, E. A., \& Jackson, A. Y. (2014). Qualitative data analysis after coding. Qualitative Inquiry, 20(6), 715719. https:// doi.org/10.1177/1077800414532435

Popham, W. (2005). Students' attitudes count. Educational Leadership, 62(5), 84-85. http://www. ascd.org/publications/educational-leadership/ feb05/vol62/num05/Students'-Attitudes-Count. aspx

Prakash, A. P., Kannan, M. P., \& Jerlin, J. E. (2014). An analysis on causes for failure in mathematics by engineering students in tamil nadu using combined overlap fuzzy clustering model (COFCLM). International Journal of Computer Applications, 94(6), 8-14. https:/ / doi.org/10.5120/16345-5676

Prakash, P., Jerlin, E., \& Fernandes, B. (2014). A study on the causes for aversion to mathematics by engineering students using fuzzy cognitive maps (FCMs). International Journal of Innovative Research in Science, Engineering and Technology, 3(3), 1014310150. https://www.ijirset.com/upload/2014/ march/39_A\%20Study.pdf

Sakiz, G., Pape, S., \& Hoy, A. (2012). Does perceived teacher affective support matter for middle school students in mathematics classrooms?. Journal of 
School Psychology, 50(2), 235-255. https://doi.org/ 10.1016/j.jsp.2011.10.005

Santos, A. (1976). A structural-functional approach to attitudes: Development and application of a theoretical framework (Unpublished Ph.D. dissertation). School of Education: Andrews University. https://digital commons.andrews.edu/dissertations/332/

Sarmah, A., \& Puri, P. (2014). Attitude towards mathematics of the students studying in diploma engineering institute (polytechnic) of sikkim. IOSR Journal of Research \& Method in Education (IOSRJRME), 4(6), 6-10. https://doi.org/10.9790/ 7388-04630610

Shaw, C., \& Shaw, V. (1999). Attitudes of engineering students to mathematics a comparison across universities. International Journal of Mathematical Education in Science and Technology, 30(1), 47-63. https:// doi.org/10.1080/002073999288102

Simmers, M. J. (2011). It's not the math they hate. Hawaii University International Conference on Mathematics and Engineering (pp. 1-48). Hawaii.

Suydam, M. N., \& Weaver, J. F. (1975). Research on mathematics learning. In J. N. Payne (Ed.), Mathematics learning in early childhood: thirtyseventh yearbook (pp. 44-67). National Council of Teachers of Mathematics.

Syam, M., \& Salim, S. (2014). The reasons behind student's disinterest in math as a major at qatar university a comparative case study. The International Conference on Social Sciences and
Humanities. Istanbul, Turkey. 173-179. http:/ / www. ocerint.org/Socioint14_ebook/papers/204.pdf

Tapia, M., \& Marsh, G. (2004). An instrument to measure mathematics attitudes. Academic Exchange Quarterly, 8(2), 16.

Varela, B. (2014). Improving engineering students' performance in higher mathematics subjects at the university of eastern philippines, catarman, northern samar philippines, through screening examination. Learning Science and Mathematics, (9), 35-40. http:// www.recsam.edu.my

Way, J., \& Relich, 1. (1993). Development of positive attitudes to mathematics: the perspective of preservice teachers. Proceedings of the Sixteenth Annual Conference of the Mathematics Education Research Group of Australasia. Brisbane.

Yang, X. (2013). Senior secondary students' perceptions of mathematics classroom learning environments in china and their attitudes towards mathematics. The Mathematics Educator, 15(1), 66-80. http:/ / math. nie.edu.sg/ame/matheduc/tme/tmeV15_1/4.pdf

Yılmaz, C., Altun, S. A., \& Olkun, S. (2010). Factors affecting students' attitude towards math: $A B C$ theory and its reflection on practice. Procedia-Social and Behavioral Sciences, 2(2), 4502-4506. https://doi.org/10.1016/j.sbspro.2010.03.720

Yonson, D. (2017). Solving word problems performance of students in L1 (Mother Tongue) and L2 (English language). International Journal of Development and Sustainability, 6(8), 628-640. https:/ /www.research gate.net/publication/319617762 
APPENDIX

\section{Interview Questions}

1) In general, how would you describe your current attitude toward mathematics?

2) What factors do you feel most influence your current attitude towards mathematics and why?

\section{http://www.ejmste.com}

